\title{
NOTE
}

\section{Macroparasites in stranded and bycaught harbour porpoises from German and Norwegian waters}

\author{
K. Lehnert ${ }^{1, *}$, J. A. Raga $^{2}$, U. Siebert ${ }^{1}$ \\ ${ }^{1}$ Forschungs- und Technologiezentrum Westkueste, Hafentoern, 25761 Buesum, Germany \\ ${ }^{2}$ Marine Zoology Unit, Cavanilles Institute of Biodiversity and Evolutionary Biology, University of Valencia, PO Box 22085, \\ 46071 Valencia, Spain
}

\begin{abstract}
Parasitological investigations were carried out on harbour porpoises Phocoena phocoena originating from 3 different areas: the German North Sea (28), the German Baltic (18) and Norwegian waters (22). The individuals were bycaught in gill-nets or found stranded during the period 1997 to 2000. A total of 7 species of parasites was identified from the investigated organs. These originated mainly from the respiratory tract and comprised 1 ascaridoid nematode (Anisakis simplex), 4 pseudaliid nematodes (Pseudalius inflexus, Torynurus convolutus, Halocercus invaginatus, Stenurus minor) and 2 trematodes (Campula oblonga, Pholeter gastrophilus). This is the first geographic record of $H$. invaginatus from German waters. Differences were found in the severity of the parasitic infection between stranded and bycaught animals as well as between porpoises from different areas. A correlation was shown between parasitic infection and observed lesions.
\end{abstract}

KEY WORDS: Harbour porpoise $\cdot$ Parasites $\cdot$ Respiratory tract $\cdot$ Pathology

\section{INTRODUCTION}

Assessments of the health status of porpoises Phocoena phocoena in German waters have been undertaken since 1990. Special attention has been paid to parasites as major agents of infection. Parasitic infections have been found in the respiratory and alimentary tract, heart, liver, pancreas and auditory/cranial sinuses (Raga 1994, Siebert et al. 2001). Infections with lung worms are commonly associated with secondary bacterial infections (Balbuena et al. 1993, Kirkwood et al. 1997, Jepson et al. 2000, Siebert et al. 2002) and are known to seriously affect the health of marine mammals. Heavy burdens of lung worms cause obstruction of the respiratory tract, impede diving ability and can lead to death (Clausen 1985, Kirkwood et al. 1997). It remains unclear why porpoises from Greenlandic waters exhibit lower levels of parasitic infection and suffer less from lesions due to parasites than porpoises from German waters (Wünschmann et al. 2001). It has been suggested that the bioaccumulation of pollutants (PCBs, DDTs etc.) caused by environmental deterioration could be responsible for the impairment of immune responses to pathogens such as bacteria, fungi or parasites (Aguilar \& Borrell 1995, Jepson et al. 1999, Siebert et al. 1999). In this study special attention was paid to the respiratory tract and to pathological lesions caused by parasites. The prevalence and abundance of parasite species in hosts stranded and bycaught and originating from different geographical areas were compared and correlated with bronchopneumonia and gastritis.

\section{MATERIALS AND METHODS}

Samples included in this investigation originated from dead harbour porpoises collected along the coasts of Schleswig-Holstein, Germany, between 1997 and 2000. All porpoises from the German North Sea (28) 


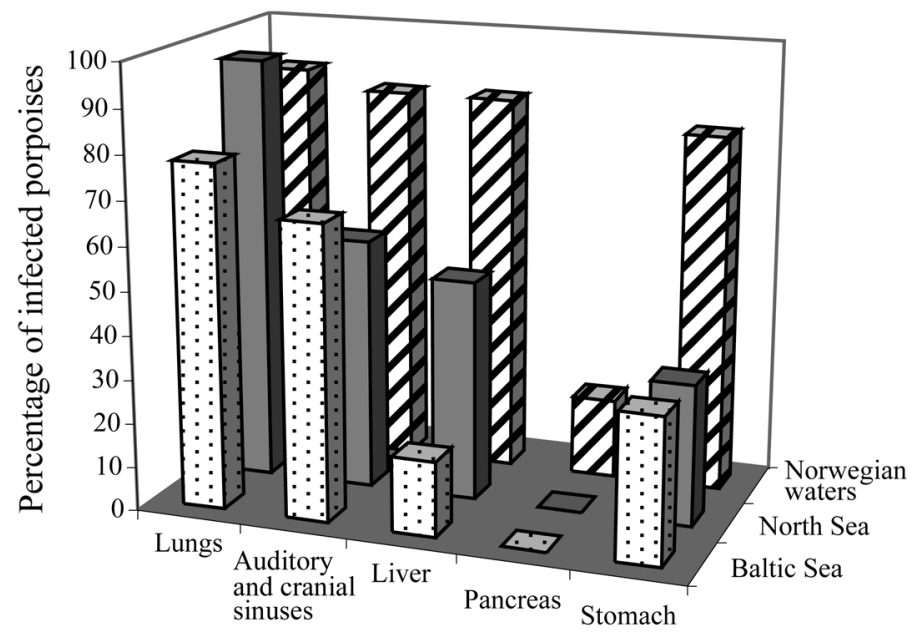

Infected Organs

Fig. 1. Phocoena phocoena. Distribution of parasitic infection in the organs of porpoises in German (North Sea and Baltic Sea) and Norwegian waters

were found stranded, while $13(72 \%)$ of the individuals from the German Baltic (18) were bycaught. Samples from Norwegian waters (22) originated from porpoises which were bycaught in commercial fishery gill-nets during 2000. The majority of the animals were stored at $-20^{\circ} \mathrm{C}$ until necropsy, and some were dissected directly.

Necropsies were performed according to international guidelines; all organs were examined macroscopically and histologically (Siebert et al. 2001). Furthermore, microbiological, serological and virological investigations were carried out on the porpoises. Parasites were collected during necropsies, preserved in $70 \%$ ethanol and identified microscopically after preparation in lactophenol according to the scientific literature (Baylis 1932, Schmidt-Ries 1940, Yamaguti 1958, 1961, Arnold \& Gaskin 1974). The level of parasitic infection was determined (during necropsy) semiquantitatively as severe, moderate or mild as described by Siebert et al. (2001). Age was determined according to Lockyer (1995) and porpoises were divided into ageclasses according to Siebert et al. (2001): $\leq 0.5 \mathrm{yr}$ (neonates and calves); 0.5 to $4 \mathrm{yr}$ (subadults); >4 yr (adults). Non-parametric tests were chosen according to the rationales indicated in Siegel \& Castellan (1988). Exact tests were calculated when small samples required their use (Mundry \& Fischer 1998), and 2-tailed p-values are indicated throughout. Fisher's exact tests and Mann-Whitney $U$-tests were calculated using SPSS 11.5.0, and Spearman correlations and corresponding $\mathrm{p}$-values using software written by $\mathrm{R}$. Mundry, Forschungs- und Technologiezentrum Westkueste, Hafentoern, Germany. Because the data frequently included tied observations, p-values were derived using a randomisation procedure.

\section{RESULTS AND DISCUSSION}

Seven species of parasites were identified from the samples investigated. Five species were nematodes: 1 ascaridoid nematode (Anisakis simplex) from the stomach and 4 pseudaliid nematodes (Pseudalius inflexus, Torynurus convolutus, Halocercus invaginatus, Stenurus minor) from the respiratory tract and the cranial sinuses. In addition, 2 trematodes (Campula oblonga, Pholeter gastrophilus) were found. P. gastrophilus was found in the duodenal ampulla (fourth stomach compartment) and C. oblonga in the liver and pancreas.

\section{Parasites from the respiratory tract}

Pseudalius inflexus, Torynurus convolutus, and Halocercus invaginatus were found in the lungs of porpoises from all areas, this being the first geographic record of $H$. invaginatus from the German North and Baltic Seas. Parasitic infection in the respiratory tract and in the ears and cranial sinuses was prevalent in most porpoises (90\%) (Fig. 1). Nematode infection in the lungs of porpoises was often of mixed species and associated with bronchopneumonia. When pooling across all regions, age-classes, and bycaught and stranded individuals, there was a highly significant positive correlation between parasitic infection and bronchopneumonia $\left(\mathrm{r}_{\mathrm{s}}=0.487, \mathrm{n}=68, \mathrm{p}<0.001\right) . T$. convolutus was found in the nasal sinuses of 2 porpoises. Regarding the severity of parasitic infection in the respiratory tract of porpoises from different areas, animals from the Baltic Sea and Norwegian waters were less affected and did not exhibit severe levels of parasitic infection (Fig. 2). However, it has to be taken into account that all Norwegian porpoises and 13 (72\%) Baltic Sea porpoises originated from bycatch, whereas all porpoises from the North Sea were stranded.

As regards lung worm infection in bycaught and stranded porpoises, bycaught porpoises were less affected by parasites and associated bronchopneumonia (parasitic infection: $\mathrm{n}=35$ bycaught, $\mathrm{n}=33$ stranded, $U=295, \mathrm{p}<0.001$; bronchopneumonia: $\mathrm{n}=$ 34 bycaught, $\mathrm{n}=29$ stranded, $U=256, \mathrm{p}=0.001$ ) (Fig. 3). In stranded individuals bronchopneumonia was found to be a common cause of death (Baker \& Martin 1992, Siebert et al. 2001). Comparing bycaught porpoises from the Baltic Sea and Norwegian waters, individuals from the Baltic were generally less affected by both parasitic infection and bronchopneumonia than Norwegian porpoises, although only prevalence and intensity of bronchopneumonia differed significantly (parasitic infection: $\mathrm{n}=13$ Baltic, $\mathrm{n}=22$ Norwegian, $U=98, \mathrm{p}=0.07$; broncho- 


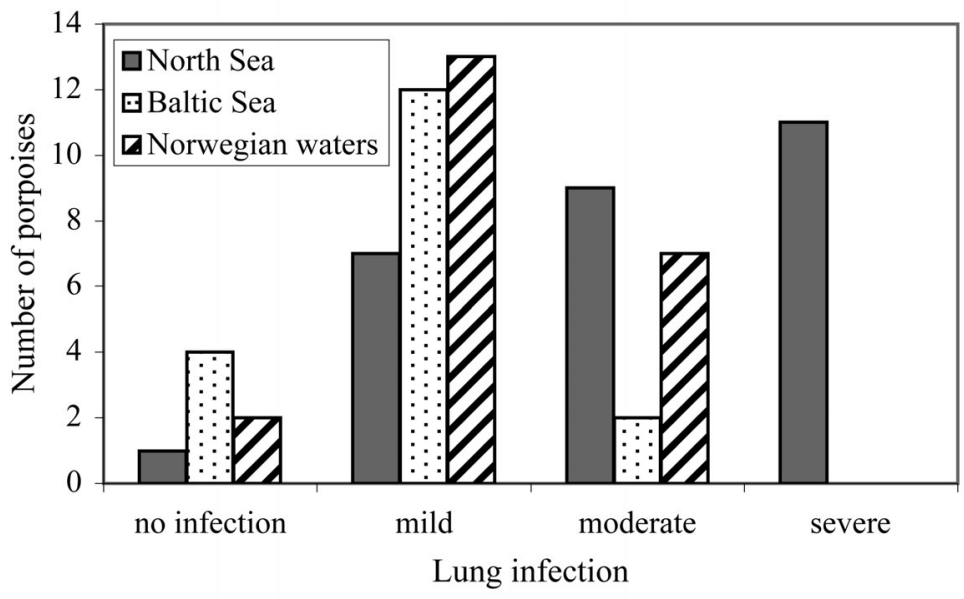

Fig. 2. Phocoena phocoena. Severity of infection by lung worms in the respiratory tract of porpoises from German and Norwegian waters

pneumonia: $\mathrm{n}=12$ Baltic, $\mathrm{n}=22$ Norwegian, $U=75$, $\mathrm{p}=0.03$ ). It remains uncertain whether this is due to differences in the immune response of the hosts from different areas or whether diet and intermediate hosts differ in these regions. Obviously, bycaught individuals represent an overview of the population while stranded porpoises might have died because of illness.

Two porpoise calves from the North and Baltic Seas examined in this study exhibited lung infection, which was determined in histology. Subadults predominantly showed mild or no infection, while all adults were infected, although severe infection was rare. These findings, which indicate a prenatal infection as suggested by Dailey et al. (1991), or an infection through lactation, are supported by Gibson et al. (1998), who found lung worms on histological slides of the lungs of newborn porpoises.

Parasitic infection and associated bronchopneumonia tended to appear more severely in adults than in subadults (Mann-Whitney $U$-test; parasitic infection: $\mathrm{n}=21$ adults, 45 subadults, $U=$ 353.5, $\mathrm{p}=0.08$; bronchopneumonia: $\mathrm{n}=$ 18 adults, 43 subadults, $U=280.5$, $\mathrm{p}=$ $0.081)$.

\section{Parasites of auditory/cranial sinuses}

The nematode Stenurus minor infects auditory and cranial sinuses (Brosens et al. 1996) and was found in 47 porpoises from all 3 examined areas; some individuals were also found in the lungs. Contrary to the results of Faulkner et al.
(1997), the infection of the porpoises examined in this work was not distributed evenly between the ears. Both stranded (62\%) and bycaught $(77 \%)$ porpoises were infected by S. minor and did not differ substantially in the severity of infection.

In this study, porpoises infected with Stenurus minor exhibited no remarkable changes in the auditory sinuses and surrounding tissues. Other authors (Brosens et al. 1996, Siebert et al. 2001, Wünschmann et al. 2001) found no pathological changes associated with $S$. minor. Furthermore, the work of Faulkner et al. (1997), in which only bycaught porpoises in a good nutritional state were examined, supports the thesis that porpoises infected with $S$. minor are able to hunt effectively. Individuals found in samples from the lungs supposedly migrated there postmortem.

\section{Parasites from liver and pancreas}

The trematode Campula oblonga was found in the liver of 36 porpoises from the North and Baltic Seas and Norwegian waters. No porpoise exhibited severe infection. When all harbour porpoises were divided into groups of individuals with and without infection of the liver, prevalence of parasitic infection in Norwegian porpoises was seen to be significantly higher $(\mathrm{n}=$ 45 subadults, $\chi^{2}=27.42, \mathrm{df}=2, \mathrm{p}<0.001$ ). In contrast to porpoises from the North and Baltic Seas, which showed no parasitic infection in the pancreas, $18 \%$ of those from Norwegian waters exhibited infections of this organ. Porpoises with trematodes in the liver and pancreas sometimes showed mild and moderate cholangitis, pericholangitis and periportal and peri-

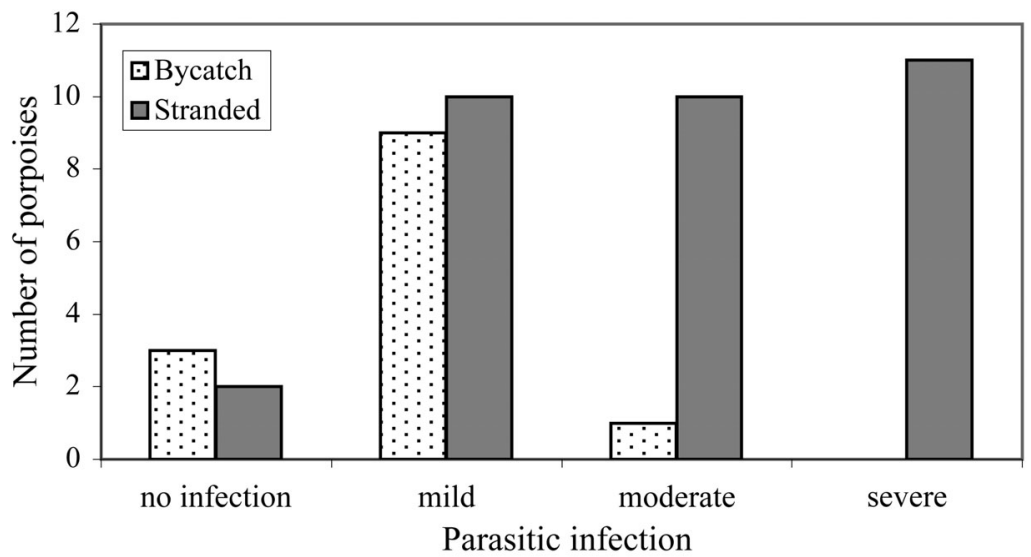

Fig. 3. Phocoena phocoena. Lung infection in bycaught and stranded porpoises from German waters 
ductular fibrosis. Siebert et al. (2001) reported $C$. oblonga in the liver and pancreas of porpoises from German waters and found similar lesions associated with the trematode. This probably does not impair porpoises seriously; however, the lesions can serve as an entrance for bacterial and fungal pathogens (Wünschmann et al. 1999).

\section{Parasites from the stomach}

Anisakis simplex was found in the first stomach compartment in 18 (80\%) of the Norwegian porpoises, in 9 $(32 \%)$ of the North Sea porpoises and in $6(28 \%)$ of the Baltic Sea porpoises. Some individuals showed infections in the second compartment which were less marked: 7 (25\%) Norwegian porpoises, and 1 porpoise each from the North (4\%) and Baltic Seas (6\%). We assumed that our ascaridoid belonged to A. simplex sensu stricto, because it is the only species of the complex cited in the North Atlantic and Baltic Sea (Mattiucci et al. 1997).

Infection with Anisakis simplex in the first stomach compartment was often accompanied by ulcers. No difference in the severity of infection between subadults and adults was found (Mann-Whitney $U$-test; Baltic Sea bycaught porpoises: $\mathrm{n}=2$ subadults, $\mathrm{n}=11$ adults, $U=9, \mathrm{p}=1$; Norwegian bycaught: $\mathrm{n}=3$ subadults, $\mathrm{n}=19$ subadults, $U=24, \mathrm{p}=0.723$; Baltic Sea stranded: $\mathrm{n}=3$ subadults, $\mathrm{n}=2$ adults, $U=2, \mathrm{p}=$ 0.8 ; North Sea stranded: $\mathrm{n}=13$ subadults, $\mathrm{n}=13$ subadults, $U=81.5, \mathrm{p}=0.977$; no alpha adjustment applied), but bycaught porpoises from Norwegian waters were infected more often and more severely than bycaught individuals from the Baltic ( $\mathrm{n}=13$ Baltic, $\mathrm{n}=22$ Norwegian, $U=50, \mathrm{p}<0.01$ ). Lick (1991) also found markedly lower infection rates with $A$. simplex in Baltic Sea porpoises. The differences probably reflect a certain species composition in the diet of porpoises in different areas. Herreras et al. (1997) also found a strong local influence in the helminth community of the digestive tract in Danish porpoises.

Regarding all porpoises, statistics showed that ulcers were associated with higher infection rates in the stomach $(7$ Mann-Whitney $U$-tests, calculated separately for 3 areas, 2 age-classes and 2 finding conditions: all except 1 (Norwegian porpoises) significant at $\mathrm{p}<0.05)$. Smith (1989) associated ulcers in the forestomach of porpoises especially with Anisakis simplex larvae.

Pholeter gastrophilus was found in 2 of the porpoises examined in the mucosa of the last stomach compartment. The trematode was accompanied by a mild granulomatous inflammation. Although it occurred rarely in individuals examined in this study, it appears to occur regularly in porpoises and, like Campula oblonga, to have no serious consequences for the host (Gibson et al. 1998). The genetic variation between Baltic and North Sea porpoises as well as Norwegian porpoises (Tolley et al. 2001) might influence their parasitation to some extent. In addition, the diet composition of porpoises from the Baltic, North Sea and Norwegian waters could result in infection with different parasitic species. Differences in parasitic infection and associated lesions between porpoises from different regions might result from the level of pollution in their respective waters. Chronic exposure to contaminants such as PCBs and organochlorine compounds has been shown to be immunosuppressive in mammalian species (Jepson 1999).

Acknowledgements. The authors thank the Institute of Marine Research in Bergen, Norway, and in particular Dr. Krystal Tolley, for the samples of Norwegian porpoises. We especially thank those who helped to collect porpoises on the German coasts and Dr. Christina Lockyer for age determination. We also thank Roger Mundry for his support in doing the statistics. The health monitoring of porpoises in SchleswigHolstein was funded by the Ministry for Environment, Nature Conservation and Agriculture of Schleswig-Holstein.

\section{LITERATURE CITED}

Aguilar A, Borrell A (1995) Pollution and harbour porpoises in the eastern North Atlantic: a review. In: Bjørge A, Donovan GP (eds) Biology of the phocoenids. Rep Int Whaling Comm, Spec Issue 16:231-242

Arnold PW, Gaskin DE (1974) Lungworms (Metastrongyloidea: Pseudaliidae) of harbour porpoise Phocoena phocoena (L. 1758). Can J Zool 53:713-735

Baker JR, Martin AR (1992) Causes of mortality and parasites and incidental lesions in harbour porpoises (Phocoena phocoena) from British waters. Vet Rec 130:554-558

Balbuena JA, Aspholm PE, Anderson KI, Björge A (1993) Lungworms (Nematoda: Pseudaliidae) of harbour porpoises (Phocoena phocoena) in Norwegian waters: patterns of colonisation. Parasitology 108:343-349

Baylis HA (1932) A list of worms parasitic in Cetacea. Discov Rep 6:392-418

Brosens L, Jauniaux T, Siebert U, Benke H, Coignoul F (1996) Observations on the helminths of harbour porpoises (Phocoena phocoena) and common guillemots (Uria aalge) from the Belgian and German coasts. Vet Rec 139: $254-257$

Clausen B, Andersen S (1985) Health status of harbour porpoise (Phocoena phocoena) from Danish waters. ICES CM 10:1-12

Dailey MD, Walsh M, Odell D, Campbell T (1991) Evidence of prenatal infection on the bottlenosed dolphin (Tursiops truncatus) with the lungworm Halocercus lagenorhynchi (Nematoda: Pseudaliidae). J Wildl Dis 27:164-165

Faulkner J, Measures LN, Whorikey FG (1997) Stenurus minor (Metastrongyloidea: Pseudaliidae) infections of the cranial sinuses of the harbour porpoise, Phocoena phocoena. Can J Zool 76:1209-1216

Gibson DI, Harris EA, Bray RA, Jepson PD, Kuiken T, Baker JR, Simpson VR (1998) A survey of the helminth parasites 
of cetaceans stranded on the coast of England and Wales during the period 1990-1994. J Zool 244: 563-574

Herreras V, Kaarstad S, Balbuena JA, Kinze CC, Raga JA (1997) Helminth parasites of the digestive tract of harbour porpoises (Phocoena phocoena) in Danish waters: a geographical comparison. Dis Aquat Org 28:163-167

Jepson PD, Bennett PM, Allchin CR, Law RJ, Kuiken T, Baker JR, Rogan E, Kirkwood JK (1999) Investigating potential associations between chronic exposure to polychlorinated biphenyls and infectious disease mortality in harbour porpoises from England and Wales. Sci Total Environ 243/ 244:339-348

Jepson PD, Baker JR, Kuiken T, Simpson VR, Kennedy S, Bennett PM (2000) Pulmonary pathology of harbour porpoises stranded in England and Wales between 1990 and 1996. Vet Rec 146:721-728

Kirkwood JK, Bennett PM, Jepson PD, Kuiken T, Simpson VR, Baker JR (1997) Entanglement in fishing gear and other causes of death in cetaceans stranded on the coasts of England and Wales. Vet Rec 141:94-98

Lick R (1991) Untersuchungen zu Lebenszyklus (KrebseFische-marine Säuger) und Gefrierresistenz anisakider Nematoden in Nord- und Ostsee. Ber Inst Meereskd Christian-Albrechts-Universität Kiel 218

Lockyer C (1995) A review on factors involved in zonation in odontocete teeth, and an investigation of the likely impact of environmental factors and major life events on harbour porpoise tooth structure. Rep Int Whaling Comm 16: 511-529

Mattiucci S, Nascetti G, Cianchi R, Paggi L and 7 others (1997) Genetic and ecological data on the Anisakis simplex complex, with evidence for a new species (Nematoda, Ascaridoidea, Anisakidae). J Parasitol 83:401-416

Mundry R, Fischer J (1998) Use of statistical programs for nonparametric tests of small samples often leads to incorrect p-values: examples from animal behaviour. Anim Behav 56:256-259

Raga JA (1994) Parasitismus bei den Cetacea. In: Robineau D, Duguy R, Robineau D, Klima M (eds) Handbuch der Säugetiere Europas: Meeressäuger, Band 6, Teil I. AulaVerlag, Wiesbaden, p 132-179

Schmidt-Ries H (1940) Die bisher bei dem kleinen Tümmler

Editorial responsibility: Murray Dailey,

Sausalito, California, USA
(Phocaena phocaena L.) festgestellten Parasiten. Zentralblatt für Bakteriologie, Parasitenkunde und Infektionskrankheiten, Abt. 1, Medizinisch-hygienische Bakteriologie, Virusforschung und tierische Parasitologie, Originale Band 145, 89-106

Siebert U, Joiris C, Holsbeek L, Benke H, Failing K, Frese K, Petzinger E (1999) Potential relation between mercury concentrations and necropsy findings in cetaceans from German waters of the North and Baltic Seas. Mar Pollut Bull 38(4):285-295

Siebert U, Wünschmann A, Weiss R, Frank H, Benke H, Frese K (2001) Post-mortem findings in harbour porpoises (Phocoena phocoena) from the German North and Baltic Seas. J Comp Pathol 124:102-114

Siebert U, Müller G, Desportes G, Weiss R, Hansen K, Baumgärtner W (2002) Pyogranulomatous myocarditis due to Staphylococcus aureus septicaemia in two harbour porpoises (Phocoena phocoena). Vet Rec 150:273-277

Siegel S, Castellan NJ (1988) Nonparametric statistics for the behavioural sciences. McGraw-Hill, New York

Smith JW (1989) Ulcers associated with larval Anisakis simplex B (Nematoda: Ascaridoidea) in the forestomach of harbour porpoises Phocoena phocoena (L.). Can J Zool 67: $2270-2276$

Tolley KA, Vikingsson GA, Rosel PE (2001) Mitochondrial DNA sequence variation and phylogenetic patterns in harbour porpoises (Phocoena phocoena) from the North Atlantic. Conserv Genet 2:349-361

Wünschmann A, Siebert U, Weiss R (1999) Rhizopusmycosis in a harbour porpoise from the Baltic Sea. J Wildl Dis 35: 391-396

Wünschmann A, Siebert U, Frese K, Lockyer C, HeideJørgensen MP, Müller G, Baumgärtner W (2001) Evidence of infectious diseases in harbour porpoises (Phocoena phocoena) hunted in the waters of Greenland and by-caught in the German North Sea and Baltic Sea. Vet Rec 148: 715-720

Yamaguti S (1958) The digenetic trematodes of vertebrates, Systema Helminthum, Vol 1. Interscience Publishers, New York

Yamaguti S (1961) The nematodes of vertebrates, Systema Helminthum, Vol 3. Interscience Publishers, New York

Submitted: May 14, 2004; Accepted: October 11, 2004

Proofs received from author(s): May 11, 2005 